\title{
The effect of a direct arterial infusion of insulin and glucose on the ovarian secretion rates of androstenedione and oestradiol in ewes with an autotransplanted ovary
}

\author{
J A Downing ${ }^{1,2}$, J Joss ${ }^{2}$ and R J Scaramuzzi ${ }^{1}$ \\ ${ }^{1}$ CSIRO Division of Animal Production, Locked Bag 1, Delivery Centre, Blacktown 2148, New South Wales, Australia \\ ${ }^{2}$ School of Biological Sciences, Macquarie University, North Ryde 2109, New South Wales, Australia \\ (Requests for offprints should be addressed to R J Scaramuzzi who is now at Department of Veterinary Basic Sciences, Royal Veterinary College, \\ Royal College Street, London NW1 OTU, UK) \\ ( A Downing is now at Department of Animal Science, University of Sydney, Camden 2750, New South Wales, Australia)
}

\begin{abstract}
Improving ewe nutrition even for short periods will increase ovulation rate. The increased nutrients must in some way affect the number of follicles that develop to the pre-ovulatory stage. One possible mechanism is that a nutrient or a metabolic hormone that responds to nutrition might act directly on the ovary to influence follicle development and/or follicle selection. In the study described here, insulin and glucose, alone or together, were infused directly into the ovarian artery of ewes with an autotransplanted ovary, for $13.5 \mathrm{~h}$ on day 11 of the oestrous cycle. The pattern of androstenedione and oestradiol secretion in response to a GnRH-stimulated LH pulse was measured $2.5 \mathrm{~h}$ before and $12.5 \mathrm{~h}$ and $24.5 \mathrm{~h}$ after the start of the infusion. Glucose or insulin infused alone had no effect on the secretion of androstenedione and
\end{abstract}

oestradiol. However, when infused together, they decreased significantly the secretion of androstenedione and, to a lesser extent, oestradiol. We suggest that the sudden availability of additional glucose and insulin increases insulin-stimulated glucose uptake by the follicle. This leads to an inhibition of LH-stimulated steroidogenesis by the ovarian follicle which occurs in the absence of any detectable changes in circulating plasma concentrations of FSH. These results show that insulin and glucose act together to influence ovarian function directly and suggest that the effects of short-term nutrition on ovulation rate may be mediated by a direct ovarian action of insulin and glucose.

Journal of Endocrinology (1999) 163, 531-541

\section{Introduction}

A short period of improved nutrition stimulates ovulation rate in sheep. For example, lupin grain supplements fed to ewes for only 4 to 6 days just before luteolysis will increase ovulation rate (Stewart \& Oldham 1986, Downing et al. 1995a). Feeding a supplement over a precisely defined period is very useful in elucidating the mechanism(s) by which changes in short-term nutrition can influence ovulation rate. Short-term intravenous administration of the energy yielding substrates, glucose and acetate, will also increase ovulation rate to a similar level to that seen when feeding lupin grain (Teleni et al. 1989a). Furthermore, the increase in ovulation rate following lupin grain feeding is strongly correlated with an increase in glucose entry rate (Teleni et al. 1989b). These studies suggest that the increased supply of glucose to the ovary could be the stimulus that increases ovulation rate.

A normal consequence of an increase in energy supply is an increase in circulating insulin. Studies with experimental animals have endeavoured to define a role for insulin in ovarian function (Liu et al. 1972, Kirchick et al. 1979, 1982, Bestetti et al. 1985). Various actions of insulin on ovarian cell function have been described. These include non-specific effects relating to general metabolic actions and growth promoting effects. Insulin actions can also be specific and these include synergism with follicle-stimulating hormone (FSH) to stimulate oestrogen and progesterone production by induction of steroidogenic enzymes (Poretsky \& Kalin 1987).

Insulin administration to gilts on high or moderate energy intake increased ovulation rate (Cox et al. 1987), while insulin given to gilts on restricted energy intake decreased follicular atresia (Matamoros et al. 1990). Daily intramuscular injections of insulin given to ewes had no significant effect on ovulation rate (Leury et al. 1990), but infusion of insulin during the late luteal phase increased ovulation rate and the number of large follicles (Hinch \& Roelofs 1986). These in vitro and in vivo studies using insulin clearly suggest that metabolic regulation of energy 
supply is likely to be involved in the mechanism by which nutrition influences ovulation rate.

The ewe with an autotransplanted ovary (Goding et al. 1967) provides a useful model which allows the direct ovarian arterial infusion of substances and the study of their effect on ovarian secretion of steroids. In the study reported here, ewes with an autotransplanted ovary were given ovarian arterial infusions of insulin, glucose or insulin plus glucose for $13.5 \mathrm{~h}$ on day 11 of the oestrous cycle. The secretion of androstenedione and oestradiol in response to a gonadotrophin-releasing hormone $(\mathrm{GnRH})$ induced luteinizing hormone (LH) pulse was determined before and at 12.5 and $24.5 \mathrm{~h}$ after the start of infusion.

\section{Materials and Methods}

\section{Animals and diet}

The animals used were 28 Border Leicester Merino cross ewes with a mean body weight of $58 \pm 0.6 \mathrm{~kg}$. These ewes had the left ovary and vascular pedicle autotransplanted (Goding et al. 1967); at the time of transplantation the right ovary was removed. The animals were studied in the normal breeding season and housed in a temperaturecontrolled $\left(20^{\circ} \mathrm{C}\right)$ room. At the start of the experiment the ewes were placed in elevated metabolism cages (Till \& Downes 1963) and a diet of hammermilled oaten straw supplemented with minerals was available ad libitum (Downing et al. 1995a).

\section{Oestrous synchronisation}

The oestrous cycles of the ewes were synchronised using an injection of $125 \mu \mathrm{g}$ Cloprostenol, an analogue of prostaglandin F2 $\alpha$ (Estrumate; ICI Pty Ltd, Sydney, Australia) and a progestagen-containing pessary (medroxy progesterone acetate; Repromap, Upjohn Pty Ltd, Sydney, Australia) inserted at the same time. Removal of the pessary 12 days later was followed by oestrus and ovulation after 48 to $96 \mathrm{~h}$; oestrus was detected by vasectomised rams. To ensure that oestrous cycles were synchronised and that all ewes were in the mid-luteal phase during the experiments, blood samples were collected by jugular venepuncture every 2 to 3 days from the first prostaglandin injection. The resulting plasma samples were assayed for progesterone. The experiment was carried out during the mid-luteal phase of the oestrous cycle that followed removal of the progestagen pessaries.

\section{Cannulations}

On the day prior to the start of blood sampling, that is 10 days following oestrus, the jugular vein draining the transplanted ovary, the contra-lateral jugular vein and the carotid artery supplying blood to the transplanted ovary were all cannulated (Downing 1994). Cannulation was carried out following an injection of a local anaesthetic (Xylocaine; Astra Pharmaceuticals, North Ryde, Australia) into the skin surrounding the cannulation site (Downing 1994). Blood sampling and infusions were started the day following cannulation.

\section{Pharmaceutical treatments}

Following cannulation and daily thereafter, all ewes were given a $4 \mathrm{ml}$ intramuscular injection of antibiotic (Hydropen; Bomac Laboratories, Castle Hill, NSW, Australia). Over the blood sampling and infusion periods all ewes were given 5000 IU heparin (Boots (Aust) Pty Ltd, North Rocks, Australia) every 3 or $4 \mathrm{~h}$, and between blood samples the cannulae were filled with heparinised saline (50 or $500 \mathrm{IU} / \mathrm{ml})$.

\section{Ovarian arterial infusion}

Solutions of insulin and glucose were made up in sterile physiological saline and were infused directly into the ovarian artery for $13.5 \mathrm{~h}$ (Collett et al. 1973) using a Harvard mechanical infusion pump (Model 944; Harvard Apparatus Ltd, Edenbridge, Kent, UK). Six ewes received an infusion of glucose, seven were infused with insulin and seven were infused with a mixture of glucose and insulin. Eight ewes were infused with saline alone and served as a control group. The glucose infusate was prepared by diluting $500 \mathrm{ml}$ of a commercially available $25 \%$ glucose solution (AHB-0224; Baxter Healthcare, Toongabbie, NSW, Australia) in $500 \mathrm{ml}$ sterile saline to which was added $1 \mathrm{~g}$ ovine albumin. The insulin solution was prepared by dissolving 2.02 $\mathrm{g}$ ovine insulin (I-9254; Sigma Chemical Company, St Louis, MO, USA) and $1 \mathrm{~g}$ ovine albumin (A-3624; Sigma Chemical Company) in 11 sterile saline (Baxter Healthcare). The combined insulin and glucose infusate was prepared by dissolving $2.02 \mathrm{~g}$ ovine insulin, $1 \mathrm{~g}$ ovine albumin and $500 \mathrm{ml}$ of the commercial glucose solution in $500 \mathrm{ml}$ sterile saline. A control infusate was prepared by dissolving $1 \mathrm{~g}$ normal sheep albumin in 1 litre sterile saline. The treatment solutions were infused at a rate of 10 to $12 \mathrm{ml} / \mathrm{h}$ through the carotid arterial cannula and were directed through the ovary by occluding the carotid artery distal to the arterial anastomosis with a pediatric manometer cuff inflated to $200 \mathrm{~mm} \mathrm{Hg}$ (Collett et al. 1973).

\section{Experimental design}

On day 11 of the oestrous cycle, 8 ewes were infused with the control solution, 7 with the insulin solution, 6 with the glucose solution and 7 with the mixture of insulin and glucose. Infusion was for a period of $13.5 \mathrm{~h}$ starting at $0900 \mathrm{~h}$. On three occasions, each ewe was injected intravenously with $150 \mathrm{ng}$ GnRH (Sigma Chemical 


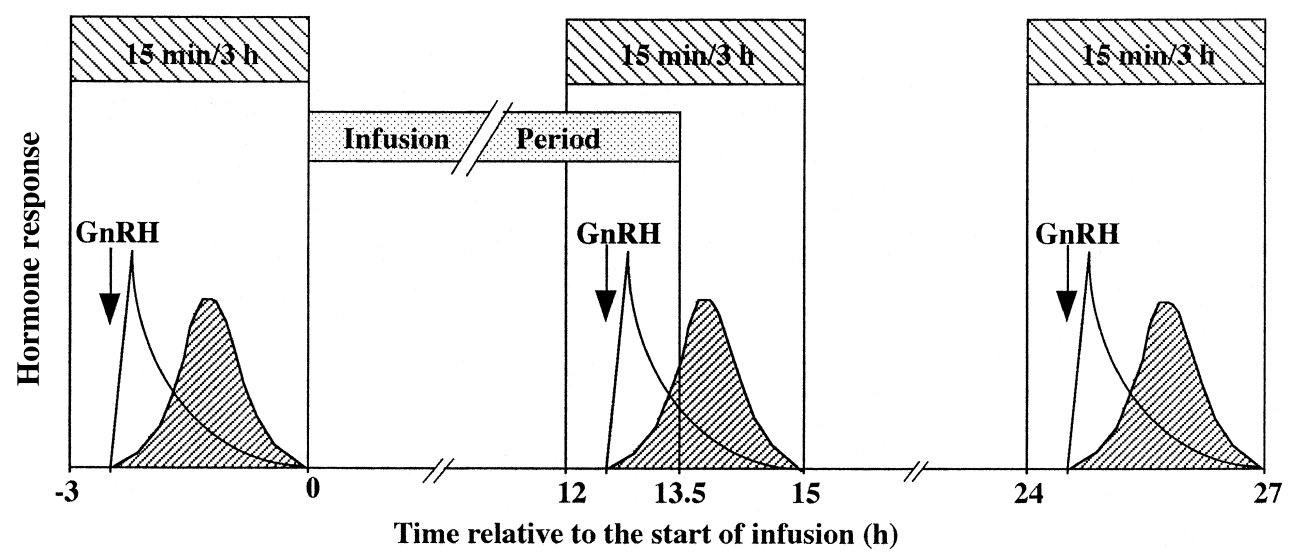

Figure 1 The experimental design. Ewes were fed an oaten straw diet and had their oestrous cycles synchronised. The ewes were given arterial infusions of saline, insulin, glucose or insulin plus glucose for $13.5 \mathrm{~h}$ on day 11 of the oestrous cycle (indicated by the stippled bar). The ewes were then given a challenge with $\mathrm{GnRH}$ injections (indicated by arrows) at $-2.5 \mathrm{~h}, 12.5 \mathrm{~h}$ and $24.5 \mathrm{~h}$ relative to the start of the infusions. Blood samples were taken every $15 \mathrm{~min}$ from $30 \mathrm{~min}$ before to $150 \mathrm{~min}$ after each of the $\mathrm{GnRH}$ injections. These three periods of blood sampling are indicated by hatched bars. Typical LH responses are represented by line graphs and steroid responses by hatched graphs.

Company); these were at $2.5 \mathrm{~h}$ before and $12.5 \mathrm{~h}$ and $24 \cdot 5 \mathrm{~h}$ after the start of the infusion. The experimental design is shown in Fig. 1.

\section{Blood sampling}

Ovarian venous $(5 \mathrm{ml})$ and jugular venous $(3 \mathrm{ml})$ blood samples were taken every $15 \mathrm{~min}$ from $30 \mathrm{~min}$ before each $\mathrm{GnRH}$ injection to $2 \cdot 5 \mathrm{~h}$ after the injection. Ovarian venous and jugular venous blood samples were also taken at intervals of 3 or $4 \mathrm{~h}$ between the intensive sampling periods.

\section{Calculation of secretion rate}

The time taken to collect each ovarian venous sample was recorded. Blood haematocrit (Collett et al. 1973) was determined for the ovarian venous samples collected hourly during the intensive sampling periods and for the samples taken 3-4 hourly. These values were used to determine hormone secretion rates (Collett et al. 1973).

\section{Hormone analysis}

Tubes containing ovarian venous and jugular venous blood samples were placed on ice immediately following collection. Within $2 \mathrm{~h}$ of collection they were centrifuged at $4{ }^{\circ} \mathrm{C}$ and the plasma stored at $-20{ }^{\circ} \mathrm{C}$.

The plasma concentrations of LH, FSH and progesterone (Downing et al. 1995a), glucose and insulin (Downing et al. 1995b), oestradiol and androstenedione (Scaramuzzi \& Downing 1995) were measured using assays previously validated in our laboratory. The LH antiserum (R29) was raised in rabbits against NIH-ovine (o) LH-S19 and showed less than $0 \cdot 1 \%$ cross-reactivity with oFSH, oLH- $\alpha$ subunit, prolactin or bovine thyrotrophin (McNeilly et al. 1986). The range of the assay was zero to $47 \cdot 9 \mathrm{ng} / \mathrm{ml}$ with a sensitivity of $0.2 \mathrm{ng} / \mathrm{ml}$. The intra- and interassay coefficients of variation for a quality control of medium concentration were $8 \cdot 1 \%$ and $3 \cdot 4 \%$ respectively. FSH was assayed using NIAMDD-anti-oFSH-1. The concentration range of the assay was $0-17.5 \mathrm{ng} / \mathrm{ml}$ with a sensitivity of $0.06 \mathrm{ng} / \mathrm{ml}$. The intra- and interassay coefficients of variation for a quality control of medium concentration were $14.6 \%$ and $11 \cdot 4 \%$ respectively. Plasma insulin concentrations were also determined using a radioimmunoassay for ovine insulin. The intra-assay coefficient of variation was $5 \cdot 7 \%$, the interassay coefficient of variation was $5 \cdot 2 \%$ and the sensitivity of the assay was $0.09 \mathrm{ng} / \mathrm{ml}$. Glucose concentrations were determined using a spectrophotometric assay.

The concentrations of androstenedione, oestradiol- $17 \beta$ and progesterone were determined by radioimmunoassay following solvent extraction (Scaramuzzi et al. 1975, Downing et al. 1995a, Scaramuzzi \& Downing 1995). The antisera for androstenedione (2119), oestradiol-17 $\beta$ (727) and progesterone (7943) were each raised in sheep against androstenedione-7-human serum albumin (HSA), 17 $\beta$ oestradiol-6-BSA and progesterone-11-BSA respectively. The cross-reactivities of each of the three steroid antisera have been reported (Campbell et al. 1990). The sensitivities (minimum detectable mass) of the androstenedione, oestradiol-17 $\beta$ and progesterone radioimmunoassays were $4 \cdot 0,2.7$ and $2.5 \mathrm{pg} /$ tube respectively. The intra- and interassay coefficients of variation for androstenedione, oestradiol-17 $\beta$ and progesterone were $10 \cdot 1 \%$ and $12 \cdot 5 \%$, 

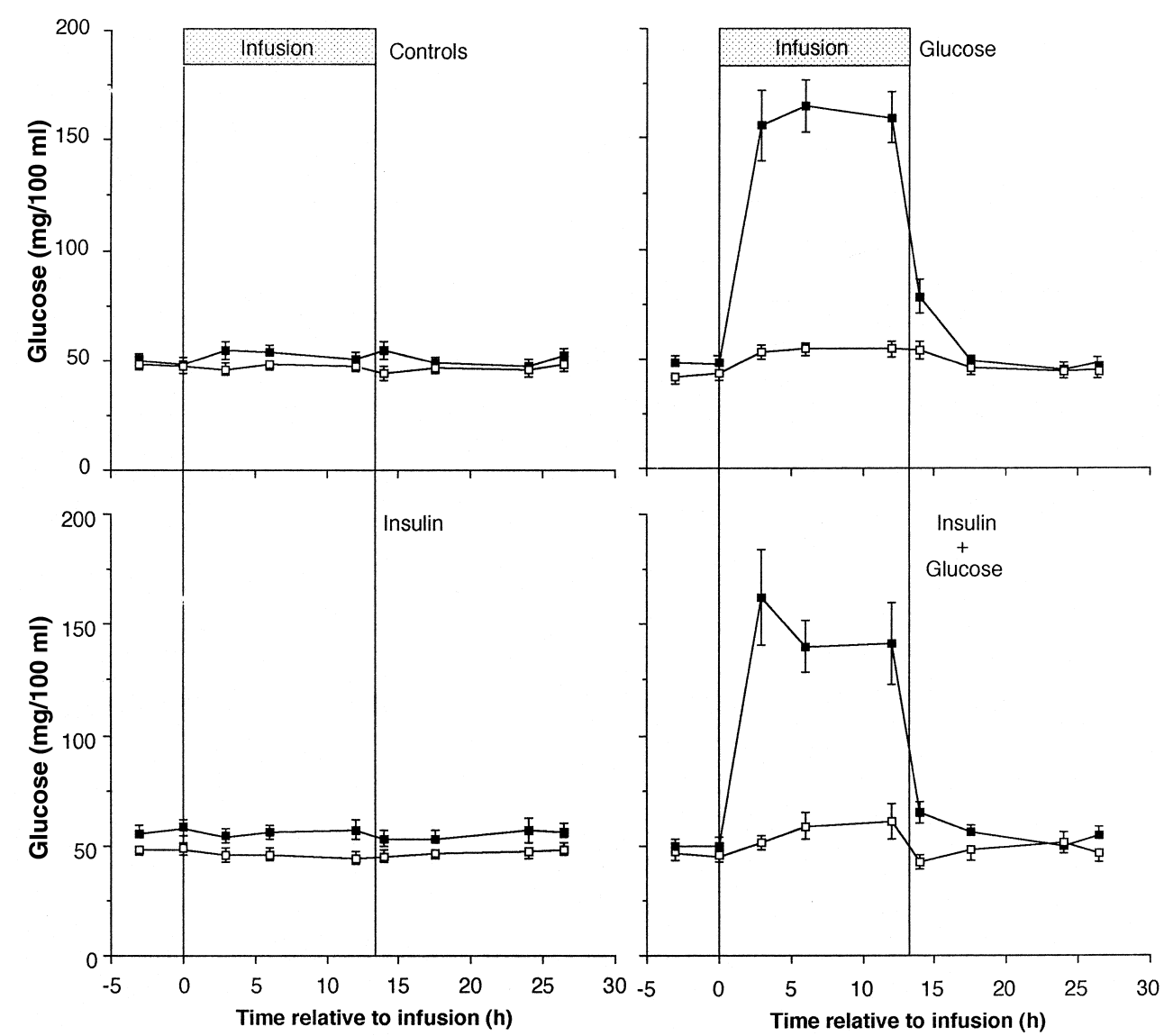

Figure 2 The mean ( \pm S.E.M.) concentration of glucose in jugular $(\square)$ and ovarian $(\boldsymbol{\square})$ venous plasma of ewes before, during and after the direct ovarian arterial infusion of saline (controls, $n=8)$, glucose $(n=6)$, insulin $(n=7)$ or insulin plus glucose $(n=7)$.

$3 \cdot 2 \%$ and $11 \cdot 9 \%$, and $3 \cdot 7 \%$ and $12 \cdot 9 \%$ respectively for quality controls of medium range concentration.

The concentration of $\mathrm{LH}$ was determined in all jugular venous plasma samples. The concentration of FSH was determined in jugular venous plasma samples collected on the hour (i.e. every 4th sample) and in the jugular venous plasma samples collected in-between these periods of intensive sampling. The concentration of glucose was determined in ovarian and jugular venous samples taken at nine sampling times during the course of the experiment. The concentration of insulin was determined in both ovarian and jugular venous plasma samples collected on the hour (i.e. every 4th sample) and in the ovarian and jugular venous plasma samples collected in-between the periods of intensive sampling. The concentrations of androstenedione and oestradiol were determined in all ovarian venous plasma samples. Progesterone concentrations were determined in samples collected by jugular venepuncture every 2 to 3 days over the pre-experimental synchronisation period and in selected ovarian venous samples.

\section{Statistical analysis}

Differences in the plasma levels of insulin, glucose and FSH were tested by a repeated measures (split plot) analysis of variance using the CLR Anova computer program on an Apple Macintosh computer (Clear Lake Research Incorporated, Houston, TX, USA).

A modified algorithm (Munro) based on the pulsar algorithm (Merriam \& Wachter 1982) was used to analyse LH pulses (Munro Zaristow Software, West Morham, Haddington, East Lothian, Scotland) on an Apple Macintosh computer. Androstenedione and oestradiol-17 $\beta$ secretion rates at the time of induced LH pulses were then selected using the manual option in Munro. The pulse parameters estimated were pulse amplitude and the area under the pulse curve. Comparisons of treatment effects were made within treatment groups and between treatment groups using a repeated measures analysis of variance with the CLR ANOVA computer program on an Apple Macintosh computer with and without the pre-treatment response as a covariate. 

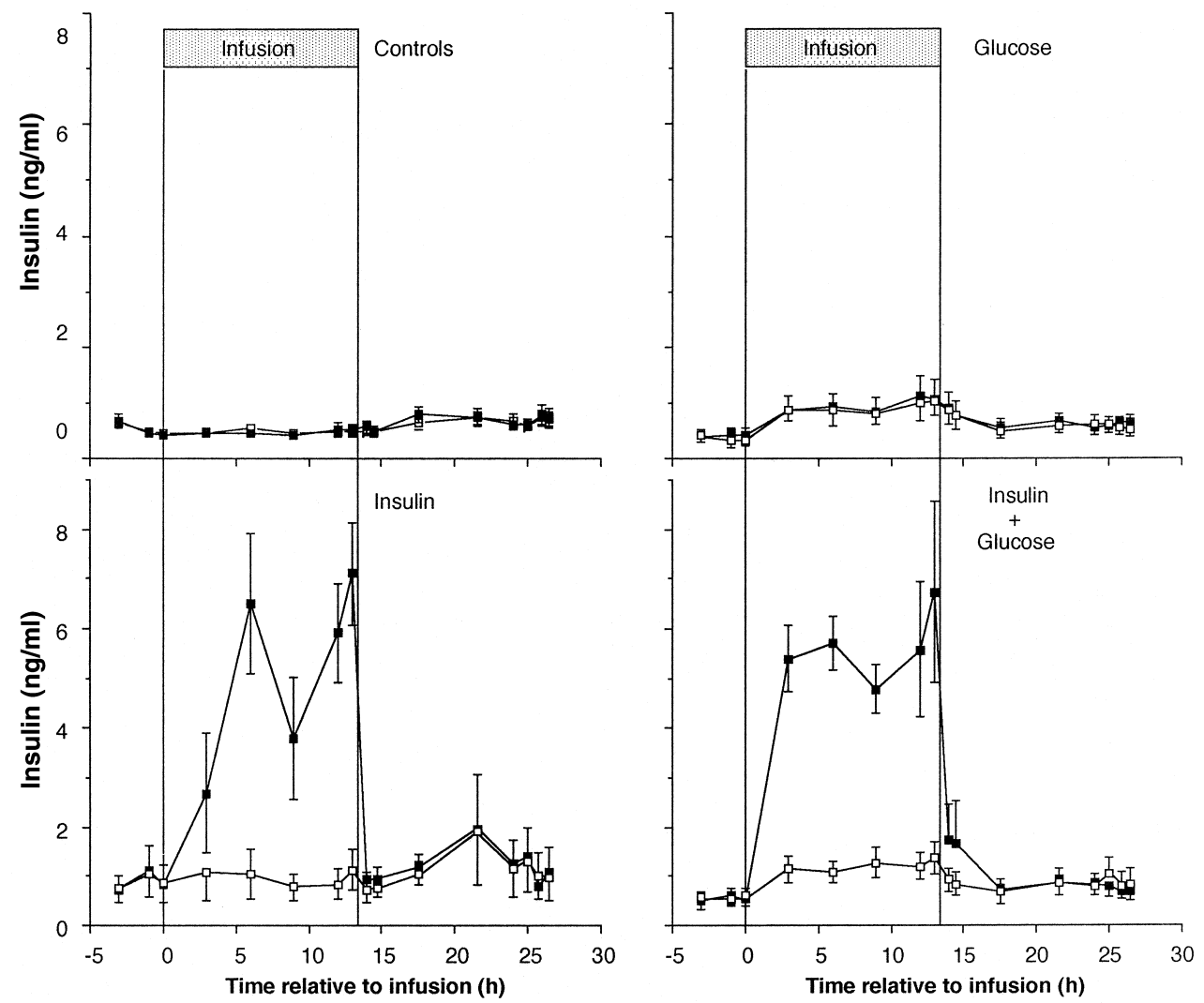

Figure 3 The mean ( \pm S.E.M.) concentration of insulin in jugular $(\square)$ and ovarian ewes before, during and after the direct ovarian arterial infusion of saline (controls, $n=8)$, glucose $(n=6)$, insulin $(n=7)$ or insulin plus glucose $(n=7)$.

\section{Results}

\section{Glucose}

The infusion of glucose into the ovarian artery significantly increased the ovarian venous plasma glucose concentration; after infusion the concentration returned rapidly to pre-infusion levels (Fig. 2). Ewes infused with glucose also had significantly higher peripheral plasma glucose concentrations in jugular venous plasma when compared with their pre-infusion concentrations (Fig. 2) indicating a slight spill-over of glucose into the systemic circulation.

\section{Insulin}

The infusion of insulin into the ovarian artery significantly increased the concentration of insulin in the ovarian venous plasma but it returned rapidly to pre-infusion concentrations after the infusion (Fig. 3). The infusion of glucose alone significantly increased the venous plasma concentrations of insulin (Fig. 3). The infusion of insulin and glucose into the ovarian artery resulted in slightly increased concentrations of insulin in jugular venous plasma (Fig. 3) indicating either a spill-over of insulin into the systemic circulation or increased secretion of endogenous insulin.

\section{GnRH-stimulated $L H$ release}

Each injection of GnRH was followed by a pulse of $\mathrm{LH}$ (Table 1). There was significant between animal variation among the pre-infusion responses to GnRH. However, within animal and within treatment there were no significant differences in LH pulse amplitude.

\section{Androstenedione secretion}

In all ewes at all times there was a pulse-like increase in the secretion of androstenedione following GnRH (Fig. 4). Secretion had increased by $15 \mathrm{~min}$ after $\mathrm{GnRH}$ and continued to increase to peak values about $60 \mathrm{~min}$ after GnRH before declining to pre-GnRH values by $120 \mathrm{~min}$ (Fig. 4). For the ewes infused with a combination of insulin and glucose into the ovarian artery there was a 
Table 1 The mean ( \pm S.E.M.) peak $\mathrm{LH}$ concentration $(\mathrm{ng} / \mathrm{ml})$ in jugular venous plasma following the injection of GnRH (150 ng i.v.). GnRH was injected pre-infusion and at $12.5 \mathrm{~h}$ and $24.5 \mathrm{~h}$ after the start of infusion. Sheep were infused with saline (control), glucose, insulin or a mixture of insulin plus glucose for $13.5 \mathrm{~h}$ on day 11 of the oestrous cycle. There were no significant differences between treatment times within treatment groups

\begin{tabular}{|c|c|c|c|}
\hline & Pre-infusion & $\begin{array}{l}12.5 \mathrm{~h} \text { after the } \\
\text { start of infusion }\end{array}$ & $\begin{array}{l}24 \cdot 5 \mathrm{~h} \text { after the } \\
\text { start of infusion }\end{array}$ \\
\hline \multicolumn{4}{|l|}{ Treatment } \\
\hline Control & $3 \cdot 5 \pm 0 \cdot 7$ & $3 \cdot 2 \pm 0 \cdot 4$ & $3 \cdot 7 \pm 0 \cdot 5$ \\
\hline Glucose & $9 \cdot 3 \pm 1 \cdot 9$ & $8 \cdot 0 \pm 1 \cdot 7$ & $7 \cdot 2 \pm 1 \cdot 1$ \\
\hline Insulin & $5 \cdot 3 \pm 2 \cdot 6$ & $5 \cdot 5 \pm 2 \cdot 5$ & $5 \cdot 5 \pm 2 \cdot 5$ \\
\hline Insulin plus glucose & $6 \cdot 2 \pm 1 \cdot 0$ & $4 \cdot 8 \pm 1 \cdot 0$ & $4 \cdot 6 \pm 0 \cdot 5$ \\
\hline
\end{tabular}

significant depression of the maximum androstenedione secretion rate (Fig. 5) at $12.5 \mathrm{~h}$ and $24.5 \mathrm{~h}$ compared with maximum pre-infusion values. In all animals the maximum secretion rate of androstenedione observed following a GnRH challenge was lower at $12.5 \mathrm{~h}$ and
$24.5 \mathrm{~h}$ than at pre-treatment. For the ewes infused with insulin alone or glucose alone there were no differences in the maximum androstenedione secretion rate at $12.5 \mathrm{~h}$ and $24.5 \mathrm{~h}$ compared with the pre-infusion values (Fig. 5).
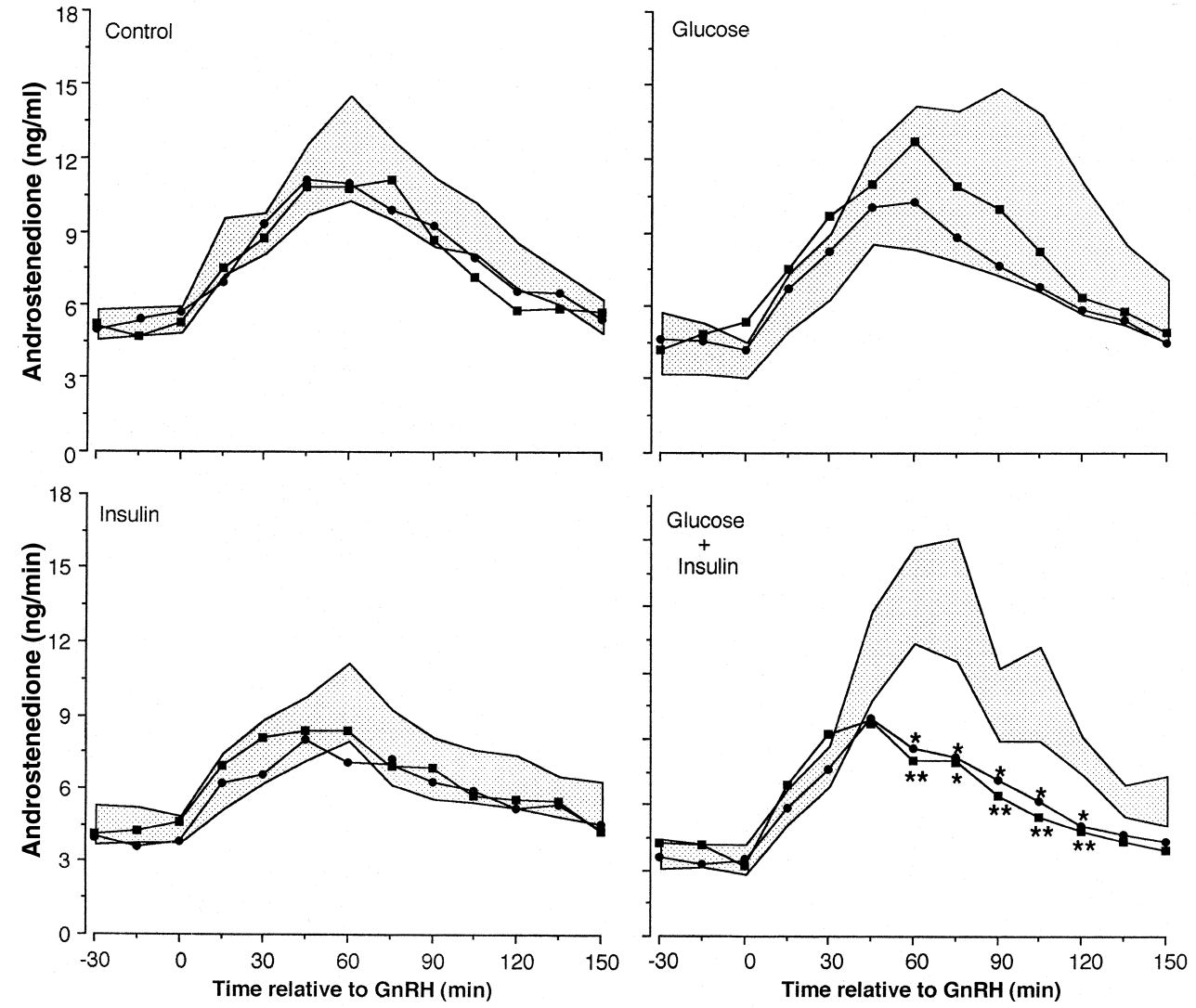

Figure 4 The acute response in mean ovarian secretion rate of androstenedione following a GnRH-induced LH pulse. Pulses were induced before (pre-treatment, stippled band), during $(12.5 \mathrm{~h}$ post-treatment, $\mathbf{\square})$ and after ( 24.5 h post-treatment, - ) the direct ovarian arterial infusion of saline (controls, $n=8)$, glucose $(n=6)$, insulin $(n=7)$ or insulin plus glucose $(n=7)$ in sheep with an autotransplanted ovary. The stippled band represents the mean pre-treatment response \pm 1 S.E.M. ${ }^{*} P<0 \cdot 05$, ${ }^{*} P<0 \cdot 01$ compared with saline-infused controls at the same time. 


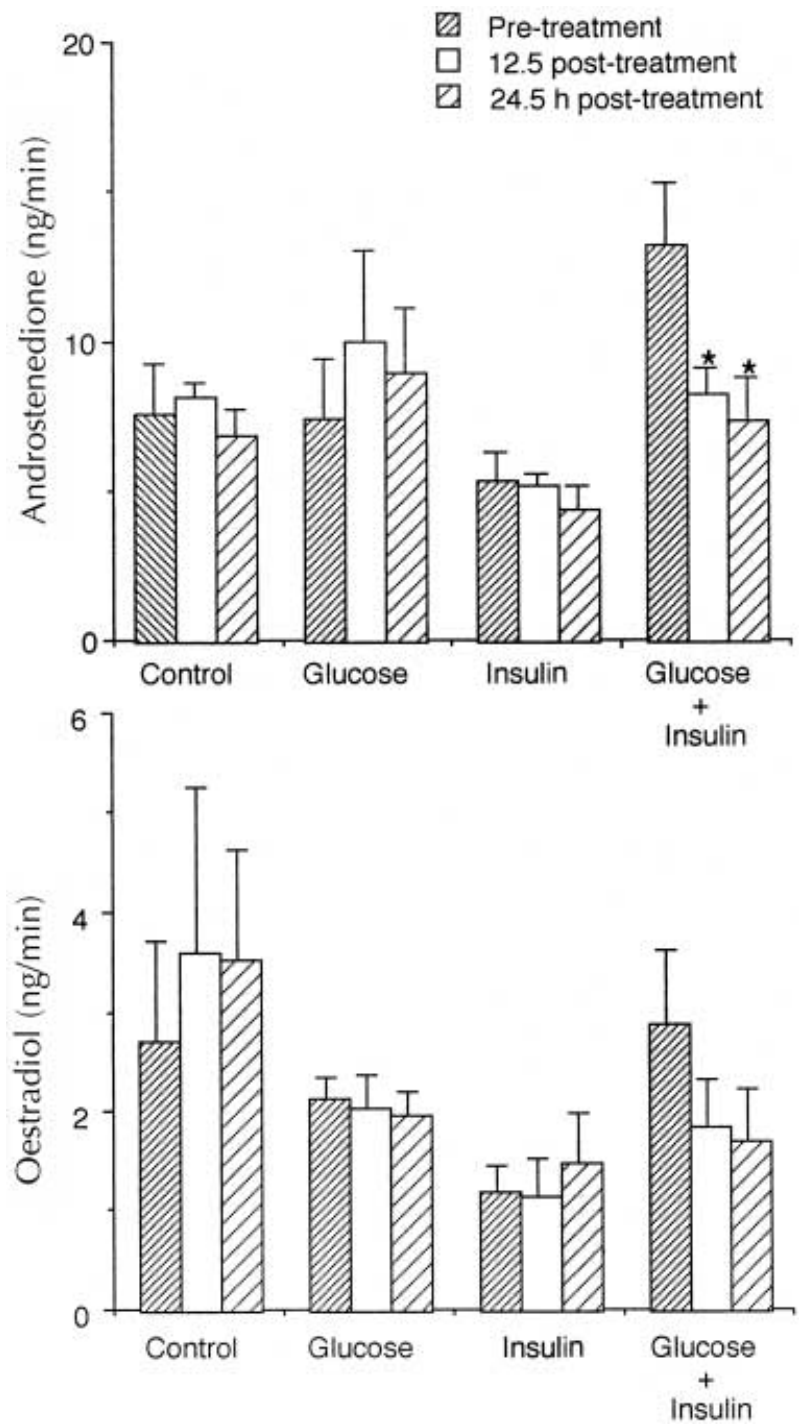

Figure 5 The maximum mean ovarian secretion rate of androstenedione (top panel) and oestradiol (bottom panel) following a GnRH-induced LH pulse. Pulses were induced before (pre-treatment), during ( $12.5 \mathrm{~h}$ post-treatment) and after $(24.5 \mathrm{~h}$ post-treatment) the direct ovarian arterial infusion of saline (controls, $n=8)$, glucose $(n=6)$, insulin $(n=7)$ or insulin plus glucose $(n=7)$ in sheep with an autotransplanted ovary. ${ }^{*} P<0 \cdot 05$ compared with pre-treatment values.

\section{Oestradiol secretion}

In all ewes at all times there was a pulse-like increase in the secretion of oestradiol following GnRH (Fig. 6). Secretion had increased by $15 \mathrm{~min}$ after $\mathrm{GnRH}$ and continued to increase to peak values at about 75 min before declining to pre-GnRH rates by 150 min (Fig. 6). For the ewes infused with a combination of insulin and glucose into the ovarian artery there were significant depressions of oestradiol secretion rate at 60,75 and $105 \mathrm{~min}$ after the injection of
GnRH (Fig. 6) at $12.5 \mathrm{~h}$ compared with the pre-infusion rates. The maximum secretion rate of oestradiol observed following a GnRH challenge was lower in 6 of 7 ewes at $12.5 \mathrm{~h}$ and 5 of 7 ewes at $24.5 \mathrm{~h}$ than at pre-treatment. However, there were no significant differences in the maximum oestradiol secretion rate at $12.5 \mathrm{~h}$ and $24.5 \mathrm{~h}$ compared with the pre-infusion maximum rate (Fig. 5).

\section{Progesterone}

The concentrations of progesterone in ovarian venous plasma (Fig. 7) were highly variable. The mean concentration tended to be higher following GnRH. However, there were no significant effects of $\mathrm{GnRH}$ or the infusion of glucose, insulin or glucose and insulin together when compared with either their respective pre-treatment control period within treatment or with the saline-infused control group (Fig. 7).

\section{FSH}

At the time of GnRH injection there were no significant differences either between treatments or between times within treatments in the mean jugular venous plasma concentration of FSH (Table 2).

\section{Discussion}

The infusion of a combination of glucose and insulin into the ovarian artery decreased the ovarian secretion rate of androstenedione. The depression in androstenedione secretion was still evident $10.5 \mathrm{~h}$ after the end of the infusion. There was also a significant decrease in oestradiol secretion, but this was not as marked. The infusion of insulin alone or glucose alone had no effect on the rate of androstenedione or oestradiol secretion. The infusion of glucose into the ovarian artery increased the jugular venous concentrations of both insulin and glucose. While this observation suggests a spill-over of glucose into the systemic circulation leading to possible peripheral effects these are not likely to be reproductively important because corresponding changes in $\mathrm{LH}$ and $\mathrm{FSH}$ concentrations were not observed.

The treatments were given on day 11 of the oestrous cycle, and at this time there are usually 1 or 2 large oestrogenic follicles present on the ovaries (Campbell et al. 1991). Most of the androstenedione and oestradiol secreted from the ovary is derived from the large oestrogenic follicle(s) (Baird \& Scaramuzzi 1976). Any change in the rate of steroid secretion is presumed to be due to changes in the function of the theca and/or granulosa cells of these follicles. Since androstenedione is derived from the thecal cells (Moor 1977, Fortune \& Hansel 1985), the decreased secretion of androstenedione observed after the arterial infusion of glucose and insulin suggests that there has been 

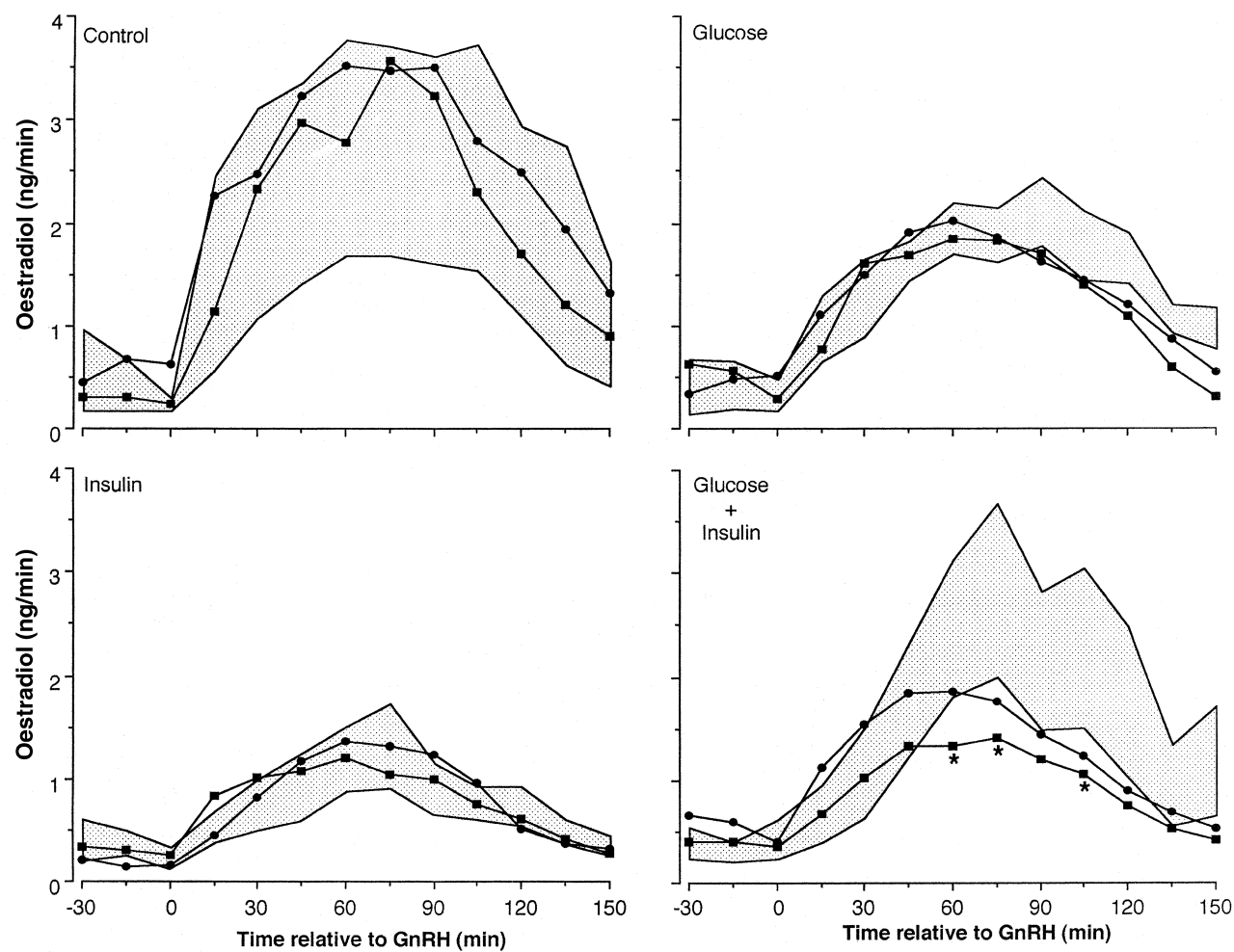

Figure 6 The acute response in the mean ovarian secretion rate of oestradiol following a GnRH-induced LH pulse. Pulses were induced before (pre-treatment, stippled band), during ( $12.5 \mathrm{~h}$ post-treatment, $\mathbf{\square})$ and after $(24.5 \mathrm{~h}$ post-treatment, - ) the direct ovarian arterial infusion of saline (controls, $n=8)$, glucose $(n=6)$, insulin $(n=7)$ or insulin plus glucose $(n=7)$ in sheep with an autotransplanted ovary. The stippled band represents the mean pre-treatment response \pm 1 S.E.M. ${ }^{\star} P<0.05$ compared with saline-infused controls at the same time.

a change in the capacity of the theca to secrete androstenedione in response to $\mathrm{LH}$. Within treatment groups there was no significant difference in the LH response following GnRH injections given before, during and after infusion. Therefore, the change in androstenedione secretion following the infusion of glucose and insulin is unlikely to be caused by a reduction in the amplitude of GnRH-stimulated LH pulses. The decreased oestradiol secretion in ewes infused with glucose and insulin could be due to decreased availability of androstenedione substrate or decreased capacity of granulosa cells to convert androstenedione to oestradiol. These data do not allow a distinction between these two possibilities.

A role for insulin in ovarian function has been reported for a number of species (human, Djursing et al. 1982, Taylor 1987; rat, Liu et al. 1972, Kirchick et al. 1982, Bestetti et al. 1985; pig, Cox et al. 1987, Matamoros et al. 1990; cattle, Harrison \& Randel 1986). Insulin receptors have been described in the ovary (Rein \& Schomberg 1982, Poretsky et al. 1985, Veldhuis et al. 1985a, Davoren et al. 1986) and for this reason alone it could be expected that insulin has a role in ovarian function. The general biological actions of insulin can be separated into acute metabolic and chronic growth promoting effects. The effect of insulin could be non-specific - that is an action common to all cells - or it could be specific to follicle cells. In most cell types insulin stimulates the uptake of glucose and other nutrients and activates enzyme systems, and in dividing cells it regulates RNA and DNA synthesis (Goldfine 1987). The metabolic effects of insulin are usually observed at low concentrations and with a rapid onset, while the growth promoting effects are observed at high concentrations with response times measured in hours or days (King et al. 1980, King \& Kahn 1981). If insulin-mediated uptake of glucose was acting on follicular cells to promote general metabolic activity, then a rapid increase in the secretion of steroids from functional, differentiated thecal and granulosa cells, following the infusion of glucose and insulin, would be expected. However, in the present work this was not observed, which suggests that the effect of glucose and insulin on ovarian function in vivo is not the result of a general stimulation of metabolic activity. The fact that the changes seen in the combined glucose and insulin infused ewes 


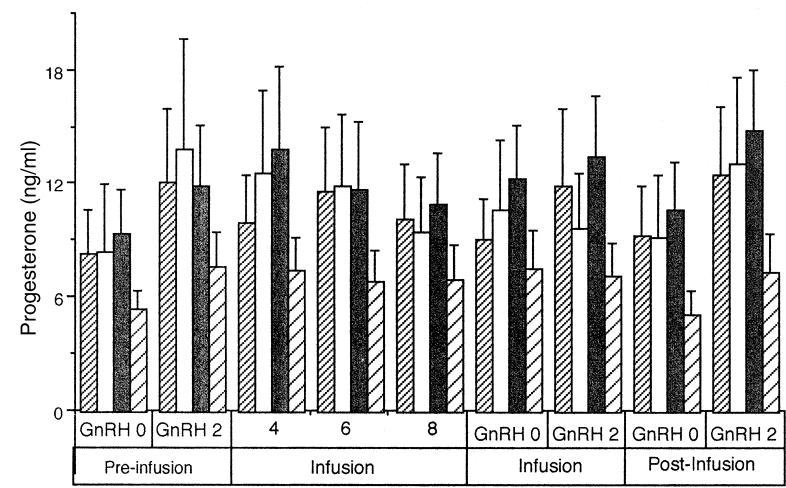

Figure 7 The concentration of progesterone in ovarian venous plasma before, during, and after infusion of saline (narrow hatched bars), glucose (open bars), insulin (solid bars) or glucose plus insulin (wide hatched bars) into the ovarian artery of ewes with an ovarian autotransplant. GnRH 0 is the sample immediately before a GnRH challenge and GnRH 2 is the sample $2 \mathrm{~h}$ after the $\mathrm{GnRH}$ challenge. Three other samples taken 4,6 and $8 \mathrm{~h}$ into the infusion were also analysed for progesterone.

were still present $10 \cdot 5 \mathrm{~h}$ after the end of the infusion further indicates that the effects on the follicle were not simply due to changes in metabolic activity.

The in vivo experiments described in the present study show that neither insulin nor glucose alone will stimulate steroid secretion from the ovary of the ewe. Therefore, it appears unlikely that insulin has a direct, specific action on steroidogenesis in the follicle. When glucose is administered systemically (for example via a jugular venous infusion) a concomitant increase in insulin secretion makes it difficult to disentangle their effects on ovarian function. However, using the ovarian autotransplant and the direct arterial infusion technique we set out to study the action of glucose on ovarian function without a concomitant increase in insulin secretion. From these experiments we can conclude that the actions of glucose on the ovary require insulin.

If the effects of the combined insulin and glucose treatment are not due to increased metabolic activity then they are probably caused by specific effects on follicular cells. In vitro, insulin will synergise with FSH to stimulate oestradiol secretion from granulosa cells (Davoren \& Hsueh 1984, Adashi et al. 1985b, Veldhuis et al. 1985b) and with $\mathrm{LH}$ to stimulate androgen production from thecal cells (Tesone et al. 1983, Cara \& Rosenfield 1988, Morley et al. 1989). These studies once again suggest that insulin infusion should increase the in vivo secretion of steroids from the ovary. The in vivo experiments described in the present study clearly show that neither insulin nor glucose alone could stimulate steroid secretion from the ovary. Therefore, it appears unlikely that insulin in vivo has a direct, stimulatory effect on the steroidogenic function of the follicle.

In vitro studies are difficult to extrapolate to the in vivo conditions especially in the case of insulin. Most in vitro studies use high levels of insulin which could downregulate the insulin receptor or exert physiological action via the insulin-like growth factor (IGF)-I receptor (Rein \& Schomberg 1982, Poretsky et al. 1985, Veldhuis et al. 1985b, Morley et al. 1989). If insulin at high concentrations in vitro down-regulates its own high affinity receptor then it could have the opposite effect to insulin at physiological concentrations in vivo. Therefore, high insulin concentrations in vitro may stimulate steroid secretion by actually antagonising the effect of insulin. Alternatively, insulin at very high concentrations may act through the IGF-I receptor. Insulin-like growth factor-I will synergise with FSH to enhance steroid secretion from granulosa cells (Adashi et al. 1984, 1985a, 1986, Davoren et al. 1985), and with LH to stimulate androgen production from the theca (Erickson et al. 1985, Cara \& Rosenfield 1988, Morley et al. 1989). If high concentrations of insulin were to activate the IGF-I receptor, enhanced steroid secretion would be expected. Under normal physiological conditions the insulin concentration observed in vivo will not activate the IGF-I receptor (Rein \& Schomberg 1982, Ontani et al. 1985). In the present study, the infusion of insulin increased the insulin concentrations in the ovarian vein plasma to levels seen in the peripheral circulation of ewes infused with glucose (Downing et al. 1995b) and to levels within the range

Table 2 The mean ( \pm S.E.M.) pre-GnRH concentration of FSH $(\mathrm{ng} / \mathrm{ml})$ in jugular venous plasma at three times (pre-infusion and $12.5 \mathrm{~h}$ and $24.5 \mathrm{~h}$ after the start of infusion) in sheep infused with saline (control), glucose, insulin or a mixture of insulin plus glucose for $13 \cdot 5 \mathrm{~h}$ on day 11 of the oestrous cycle. There were no significant differences between times within treatment groups or between treatment groups

\begin{tabular}{|c|c|c|c|}
\hline & Pre-infusion & $\begin{array}{l}12 \cdot 5 \mathrm{~h} \text { after the } \\
\text { start of infusion }\end{array}$ & $\begin{array}{l}24 \cdot 5 \mathrm{~h} \text { after the } \\
\text { start of infusion }\end{array}$ \\
\hline \multicolumn{4}{|l|}{ Treatment } \\
\hline Control & $0.94 \pm 0.13$ & $1 \cdot 49 \pm 0 \cdot 21$ & $1 \cdot 06 \pm 0 \cdot 12$ \\
\hline Glucose & $1 \cdot 21 \pm 0 \cdot 35$ & $1 \cdot 54 \pm 0 \cdot 30$ & $1 \cdot 24 \pm 0 \cdot 33$ \\
\hline Insulin & $0.68 \pm 0.23$ & $0 \cdot 80 \pm 0 \cdot 17$ & $0 \cdot 91 \pm 0 \cdot 25$ \\
\hline Insulin plus glucose & $1 \cdot 09 \pm 0 \cdot 13$ & $0 \cdot 89 \pm 0 \cdot 11$ & $0 \cdot 77 \pm 0 \cdot 15$ \\
\hline
\end{tabular}


seen following lupin feeding (Downing et al. 1995a). These insulin levels probably did not stimulate the IGF-I receptor.

If it is assumed that the effects of insulin and glucose on steroid secretion are not a result of increased metabolic activity or specific effects on follicular cells, then they could be due to effects on cellular growth. Increased insulin-mediated uptake of glucose could act to stimulate the growth of follicular cells at the expense of their ability to acquire or maintain differentiated functions. Fully differentiated granulosa cells from rat follicles require continued exposure to FSH to maintain oestradiol synthesis (Peluso et al. 1991). When these cells were exposed to insulin in perfusion culture, their ability to secrete oestradiol was decreased and their mitogenic activity increased (Peluso et al. 1991). Thus, insulin was able to stimulate mitogenic activity and simultaneously to suppress oestradiol secretion in these fully differentiated granulosa cells. If similar actions occur in vivo, they could explain the decrease in androstenedione and oestradiol secretion from large oestrogenic follicles following the combined infusion of insulin and glucose.

The short-term studies described in this paper set out to investigate how nutritional supplements might increase ovulation rate. Glucose acts on the ovary to increase ovulation rate by increasing the number of ovulatory follicles (Downing et al. 1995b). In this experiment, insulin and glucose decreased the secretion of oestradiol (Fig. 6) and hence feedback control of FSH. We suggest that glucose and insulin act on the ovary to increase ovulation rate because there is a corresponding increase in the number of follicles developing to the ovulatory stage. We speculate that the acute response to increased insulin and glucose availability is the inhibition of oestradiol secretion by the dominant follicle leading to a reduced feedback control of FSH. We have observed this in ewes infused systemically with glucose in the late luteal phase (Downing et al. 1995b). In this experiment FSH levels remained elevated for $24 \mathrm{~h}$ after luteolysis in the glucose infused ewes while they declined significantly within $3 \mathrm{~h}$ in control ewes (Downing et al. 1995b). At luteolysis the ovulatory follicle has the functional characteristics required to overcome the decline in FSH that occurs following luteolysis. Subordinate follicles do not and they undergo atresia. If the post-luteolysis fall in FSH is delayed by even a few hours additional ovulatory follicles may develop. We suggest that short-term nutritional effects on ovulation rate are the result of changes in the dynamic feedback interrelationships between oestradiol and FSH in the $24 \mathrm{~h}$ after luteolysis.

\section{Acknowledgements}

We wish to thank Donna Paliskis, Bronwyn Gordon, Steve Harmer, Joanne Murray, Alan Rintoul and Peter
Speck for expert technical assistance. Antiserum to progesterone was supplied by Dr R M Hoskinson (CSIRO Division of Animal Production, Prospect, Australia). Prolactin-free and growth hormone-free plasma from hypophysectomized ewes was supplied by Dr I J Clarke (Prince Henry's Institute of Medical Research, Clayton, Victoria, Australia). Iodination grade ovine LH (G3-233) was supplied by Dr H Papkoff (University of San Francisco, San Francisco, CA, USA). The provision of reagents by the National Hormone and Pituitary Program (USA) for the assay of ovine LH, FSH, growth hormone and prolactin is also gratefully acknowledged.

\section{References}

Adashi EY, Resnick CE, Svoboda ME \& Van Wyk JJ 1984 A novel role for somatomedin-C in the cytodifferentiation of the ovarian granulosa cell. Endocrinology 115 1227-1229.

Adashi EY, Resnick CE, Brodie AMH, Svoboda ME \& van Wyk JJ 1985a Somatomedin-C-mediated potentiation of follicle-stimulating hormone-induced aromatase activity of cultured rat granulosa cells. Endocrinology 117 2313-2320.

Adashi EY, Resnick CE, D'Ercole AJ, Svoboda ME \& Van Wyk JJ $1985 b$ Insulin-like growth factors as intraovarian regulators of granulosa cell growth and function. Endocrine Reviews 6 400-420.

Adashi EY, Resnick CE, Svoboda ME \& Van Wyk JJ 1986 Somatomedin-C enhances induction of luteinizing hormone receptor by follicle-stimulating hormone in cultured rat granulosa cells. Endocrinology 118 149-155.

Baird DT \& Scaramuzzi RJ 1976 The source of ovarian oestradiol and androstenedione in sheep during the luteal phase. Acta Endocrinologica 83 402-409.

Bestetti G, Locatelli V, Tirone F, Rossi GL \& Muller EE 1985 One month of streptozotocin-diabetes induces different neuroendocrine and morphological alterations in the hypothalamo-pituitary axis of male and female rats. Endocrinology 117 208-216.

Campbell BK, Scaramuzzi RJ, Downing JA \& Evans G 1990 Steroid secretion rates and plasma binding activity in androstenedioneimmune ewes with an autotransplanted ovary. Journal of Reproduction and Fertility 89 485-496.

Campbell BK, McNeilly AS, Mann GE \& Baird DT 1991 The effect of stage of estrous cycle and follicular maturation on ovarian inhibin production in sheep. Biology of Reproduction 44 483-490.

Cara JF \& Rosenfield RL 1988 Insulin-like growth factor I and insulin potentiate luteinizing hormone-induced androgen synthesis by rat ovarian thecal-interstitial cells. Endocrinology 123 733-739.

Collett RA, Land RB \& Baird DT 1973 The pattern of progesterone secretion by the autotransplanted ovary of the ewe in response to ovine luteinizing hormone. Journal of Endocrinology 56 403-411.

Cox NM, Stuart MJ, Althen TG, Bennett WA \& Miller HW 1987 Enhancement of ovulation rate in gilts by increasing dietary energy and administering insulin during follicular growth. Journal of Animal Science 64 507-516.

Davoren JB \& Hsueh AJW 1984 Insulin enhances FSH-stimulated steroidogenesis by cultured rat granulosa cells. Molecular and Cellular Endocrinology 35 97-105.

Davoren JB, Hsueh AJW \& Li CH 1985 Somatomedin C augments FSH-induced differentiation of cultured rat granulosa cells. American Journal of Physiology 249 E26.

Davoren JB, Kasson BG, Li CH \& Hsueh AJW 1986 Specific insulinlike growth factor (IGF)-I and -II binding sites on rat granulosa cells: relation to IGF action. Endocrinology 119 2155-2162.

Djursing H, Nyholm HC, Hagen C, Carstensen L \& Pederson LM 1982 Clinical and hormonal characteristics in women with 
anovulation and insulin-treated diabetes mellitus. American Journal of Obstetrics and Gynecology 143 876-880.

Downing JA 1994 Interactions of nutrition and ovulation rate in ewes. PhD Thesis, Macquarie University, North Ryde, Australia.

Downing JA, Joss J, Connell P \& Scaramuzzi RJ 1995a Ovulation rate and the concentrations of gonadotrophic and metabolic hormones in ewes fed lupin grain. Journal of Reproduction and Fertility 103 137-145.

Downing JA, Joss J \& Scaramuzzi RJ 19956 Ovulation rate and the concentrations of gonadotrophins and metabolic hormones in ewes infused with glucose during the late luteal phase of the oestrous cycle. Journal of Endocrinology 146 403-410.

Erickson GF, Magoffin DA, Dyer CA \& Hofeditz C 1985 The ovarian androgen producing cells: a review of structure/function relationships. Endocrine Reviews 6 371-399.

Fortune JE \& Hansel W 1985 Concentrations of steroids and gonadotropins in follicular fluid from normal heifers and heifers primed for superovulation. Biology of Reproduction 32 1069-1079.

Goding JR, McCracken JA \& Baird DT 1967 The study of ovarian function in the ewe by means of a vascular autotransplantation technique. Journal of Endocrinology 39 37-52.

Goldfine ID 1987 The insulin receptor: molecular biology and transmembrane signalling. Endocrine Reviews 8 235-253.

Harrison LM \& Randel RD 1986 Influence of insulin and energy intake on ovulation rate, luteinizing hormone and progesterone in beef heifers. Journal of Animal Science 63 1228-1235.

Hinch GN \& Roelofs JHW 1986 Lupin feeding and insulin infusion during the late luteal phase can increase ovulation rate in sheep. Proceedings of the Australian Society for Reproductive Biology 1843 (Abstract).

King GL \& Kahn CR 1981 Non-parallel evolution of metabolic and growth-promoting functions of insulin. Nature 292 644-646.

King GI, Kahn CR, Rechler MM \& Nissely SP 1980 Direct demonstration of separate receptors for growth and metabolic activities of insulin and multiplication-stimulating activity (an insulin-like growth factor) using antibodies to the insulin receptor. Journal of Clinical Investigation 66 130-140.

Kirchick HJ, Keyes PL \& Frye BE 1979 Etiology of anovulation in the immature alloxan-diabetic rat treated with pregnant mare's serum gonadotropin: absence of the preovulatory luteinizing hormone surge. Endocrinology 102 1867-1873.

Kirchick HJ, Keyes PL \& Frye BE 1982 Restoration of the LH surge and ovulation by insulin in alloxan-diabetic immature rats treated with pregnant mare's serum gonadotrophin. Acta Endocrinologica 100 266-273.

Leury BJ, Murray PJ \& Rowe JB 1990 Effect of nutrition on the response in ovulation rate in Merino ewes following short-term lupin supplementation and insulin administration. Australian Journal of Agricultural Research 41 751-759.

Liu FTY, Lin HS \& Johnson DC 1972 Serum FSH, LH and the ovarian response to exogenous gonadotropins in alloxan diabetic immature female rats. Endocrinology 9 1172-1179.

McNeilly AS, Jonassen JA \& Fraser HM 1986 Suppression of follicular development after chronic LHRH immunoneutralization in the ewe. Journal of Reproduction and Fertility 76 481-490.

Matamoros IA, Cox NM \& Moore AB 1990 Exogenous insulin and additional energy affect follicular distribution, follicular steroid concentrations, and granulosa cell human chorionic gonadotropin binding in swine. Biology of Reproduction 43 1-7.

Merriam GR \& Wachter KW 1982 Algorithms for the study of episodic hormone secretion. American Journal of Physiology 243 E310-E318.

Moor RM 1977 Sites of steroid production in ovine Graafian follicles in culture. Journal of Endocrinology 73 143-150.
Morley P, Calaresu FR, Barbe GJ \& Armstrong DT 1989 Insulin enhances luteinizing hormone-stimulated steroidogenesis by porcine theca cells. Biology of Reproduction 40 735-743.

Ontani T, Maruo T, Yukimur N \& Mochizuki M 1985 Effect of insulin on porcine granulosa cells: implications of a possible receptor mediated action. Acta Endocrinologica 108 104-110.

Peluso J, Delidow BC, Lynch J \& White BA 1991 Follicle-stimulating hormone and insulin regulation of $17 \beta$-estradiol secretion and granulosa cell proliferation within immature rat ovaries maintained in perifusion culture. Endocrinology 128 191-196.

Poretsky L \& Kalin MF 1987 The gonadotropic function of insulin. Endocrine Reviews 8 132-141.

Poretsky L, Grigorescu F, Seibel M, Moses AC \& Flier JS 1985 Distribution and characterization of insulin and insulin-like growth factor I receptors in normal human ovary. Journal of Clinical Endocrinology and Metabolism 61 728-734.

Rein MS \& Schomberg DW 1982 Characterization of insulin receptors on porcine granulosa cells. Biology of Reproduction $\mathbf{2 6}$ (Suppl 1) 113 (Abstract).

Scaramuzzi RJ \& Downing JA 1995 The in vivo effects of fibroblast growth factor and epidermal growth factor on the secretion of oestradiol, androstenedione and progesterone by the autotransplanted ovary in the ewe. Journal of Endocrinology 146 301-311.

Scaramuzzi RJ, Corker CS, Young G \& Baird DT 1975 Production of antisera to steroid hormones in sheep. In Steroid Immunoassay. Eds EHD Cameron, SG Hillier \& K Griffiths, pp 111-122. Cardiff: Alpha Omega.

Stewart R \& Oldham CM 1986 Feeding lupins for 4 days during the luteal phase can increase ovulation rate. Proceedings of the Australian Society of Animal Production 16 367-370.

Taylor SI 1987 Insulin action and inaction. Clinical Research 35 459-465.

Teleni E, King WR, Rowe JB \& McDowell GH 1989a Lupins and energy-yielding nutrients in ewes. I. Glucose and acetate biokinetics and metabolic hormones in sheep fed a supplement of lupin grains. Australian Journal of Agricultural Research 40 913-924.

Teleni E, Rowe JB, Croker KP, Murray PJ \& King WR 1989 b Lupins and energy-yielding nutrients in ewes. II. Responses in ovulation rate in ewes to increased availability of glucose, acetate and amino acids. Reproduction, Fertility and Development 1 117-125.

Tesone M, Ladenheim RG, Oliveira-Filoho RM, Chiazzui VC, Foglia VG \& Chareau EH 1983 Ovarian dysfunction in streptozotocin-induced diabetic rats. Proceedings of the Society for Experimental Biology and Medicine 174 123-130.

Till AR \& Downes AM 1963 A metabolism cage for sheep. Laboratory Practice 12 1006-1009.

Veldhuis JD, Furlanetto RW, Juchter D, Garmwey J \& Veldhuis P 1985 a Tropic actions of human somatomedin C/insulin-like growth factor I on ovarian cells: in vitro studies with swine granulosa cells. Endocrinology 116 1235-1242.

Veldhuis JD, Kolp LA, Juchter D, Veldhuis PP \& Garmey JC 1985b Mechanisms subserving insulin's differentiating actions on progestin biosynthesis by ovarian cells: studies with cultured swine granulosa cells. Endocrinology 116 651-659.

Received 28 July 1997

Revised manuscript received 22 January 1998 Final version of manuscript received 8 March 1999 Accepted 22 July 1999 